The Spectrum of

Clean Energy Innovation

\title{
NREL Innovations Contribute to an Award-Winning Small Wind Turbine
}

The Skystream 3.7 wind turbine is the result of a decade-long collaboration between the National Renewable Energy Laboratory (NREL) and Southwest Windpower, a commercially successful small wind turbine manufacturer. NREL drew heavily on its research experience to incorporate innovations into the Skystream 3.7, including a unique blade design that makes the wind turbine more efficient and quieter than most.

Small wind turbines are electric generators that utilize wind energy to produce clean, emissions-free power for individual homes, farms, and small businesses. With this simple and increasingly popular technology, individuals can generate their own power and cut their energy bills while helping to protect the environment.

According to the American Wind Energy Association (AWEA), the United States leads the world in both the manufacture and the installed capacity of small wind turbines, which are defined as having rated capacities of 100 kilowatts (kW) and less. AWEA's Small Wind Turbine Market report showed that in 2009, despite an ongoing recession, the small wind turbine market grew by $15 \%$ in the United States. The small turbine domestic and international markets are expected to continue their strong growth through the next decade, and innovative new turbines like the Skystream 3.7 will be essential for the United States to maintain its leadership position.

Engineers at NREL's National Wind Technology Center (NWTC) began working with Southwest Windpower in 2001 to develop its Skystream 3.7 wind turbine, which is now rated at $2.4 \mathrm{~kW}$.

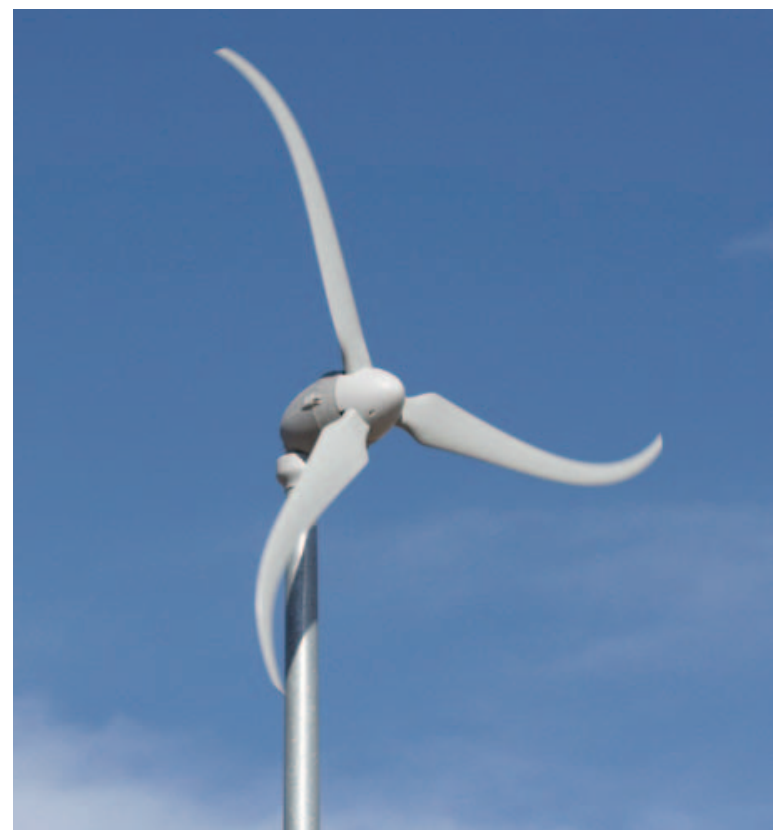

The Skystream 3.7 small wind turbine is engineered to quietly and efficiently produce power from low-speed winds. The turbine was designed by Southwest Windpower with help from NREL.

Credit: Jim Green, NREL

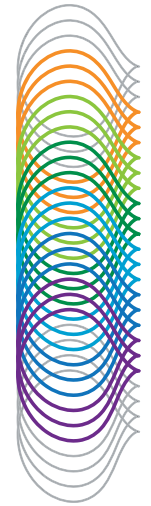

Fundamental Science

Market-Relevant Research

Systems Integration

Testing and Validation

Commercialization

Deployment

Through deep technical expertise and an unmatched breadth of capabilities, NREL leads an integrated approach across the spectrum of renewable energy innovation. From scientific discovery to accelerating market deployment, NREL works in partnership with private industry to drive the transformation of our nation's energy systems.

This case study illustrates NREL's innovations and contributions in Market-Relevant Research through Commercialization.

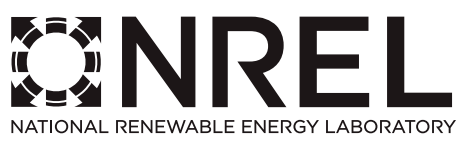

NREL is a national laboratory of the U.S. Department of Energy, Office of Energy Efficiency and Renewable Energy, operated by the Alliance for Sustainable Energy, LLC. 
"NREL assisted Southwest Windpower with the turbine's design, embedding the latest turbine technology advances from research at the NWTC," says Trudy Forsyth, NREL's small wind project lead.

When the wind turbine was commercially launched in 2006, its ease in installation, operation, and maintenance won the company the "Best of What's New" Award from Popular Science magazine, and it was recognized by Time Magazine as one of the "Best Inventions in 2006."

Southwest Windpower's key innovation for the Skystream 3.7 turbine was the use of a high-efficiency permanent-magnet generator with a unique slotless stator. Such generators generally work by spinning a permanent magnet inside a ring of coiled wires, called a stator.

Most stators are made by winding wires around a metal ring with slots in it to hold the wire. Unfortunately, at low speed, the generators tend to stick, or "cog," at a position where the rotating magnet aligns with one of the metal "teeth" in the stator, that is, the metal segments between the slots.

In the Skystream 3.7, the stator wires are wound continuously around a metal core in a process that avoids the use of slots and teeth. This slotless stator avoids the cogging normally associated with permanent-magnet generators, allowing the turbine and its generator to start turning at low wind speeds and to continue turning smoothly when the wind slows down. As a result, the wind turbine is able to capture more energy from low-speed winds.

In addition, drawing on NREL's acoustic research, the wind turbine is quieter than most. That research called for a lower rotating speed and for blades with a blunt leading edge and a sharp, thin trailing edge. The turbine also employs airfoils patented by NREL that are less sensitive to degradation caused by dirt or bugs building up on the blades.

The Skystream 3.7 wind turbine also draws on an idea to use the turbine's generator to cause it to stall in potentially damaging high wind speeds. Combined with the turbine's downwind design, that approach simplifies the turbine, avoiding the need for a tail vane.

Yet another innovation is the turbine's integrated electrical design. Southwest Windpower specifically designed the electrical characteristics of its generator to take advantage of the turbine's built-in power inverter, which delivers alternating current to the home. This electrical design avoids the energy losses that sometimes occur in small wind turbines and delivers higher system efficiency than most small wind turbines on the market.

NREL installed and started testing an early prototype of this turbine at the NWTC in 2003. As an accredited testing organization, NREL tests included power performance, safety and function, noise, and partial load tests to international standards. NREL continues to operate a Skystream 3.7 wind turbine next to the NWTC's site entrance.

Southwest Windpower places heavy emphasis on the suburban market. Its standard product offering is to mount the wind turbine on a 10.2-meter (33.5-foot) tower, but the company also offers a range of towers up to 21.3 meters (70 feet) in height. Taller towers harvest a higher wind speed and make the turbine more economical.

The commercial success of the Skystream 3.7 wind turbine has helped Southwest Windpower to become the largest manufacturer of small wind turbines in the world. According to AWEA's 2010 Small Wind Turbine Global Market Study, Southwest Windpower sold 11,700 kW worth of turbines in 2009, which is 2,500 kW more than its nearest competitor.

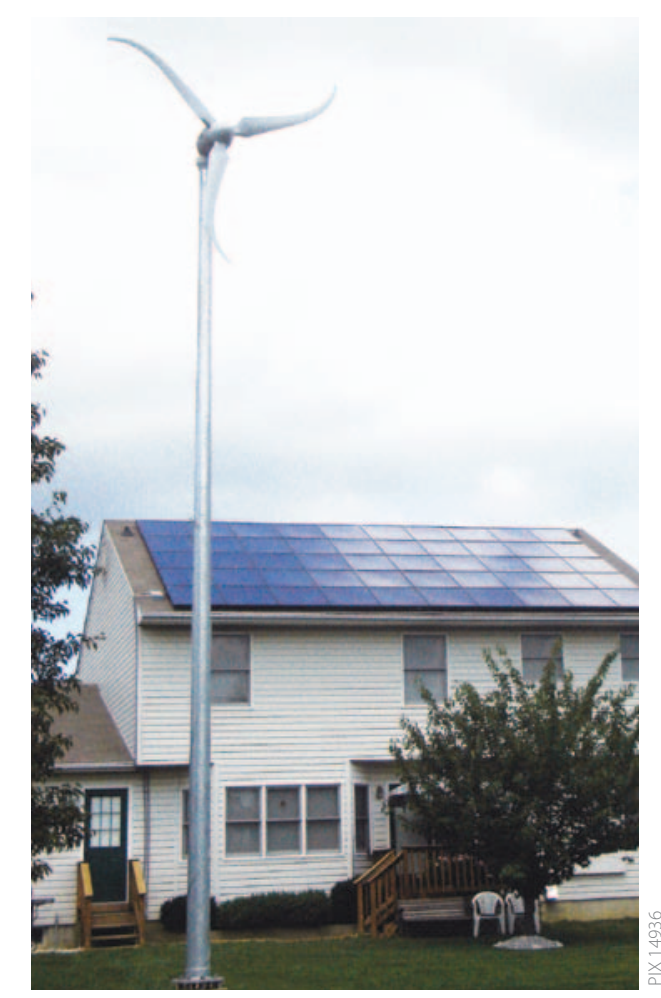

Southwest Windpower's Skystream 3.7 wind turbine in a suburban backyard. Courtesy of Southwest Windpower

\section{National Renewable Energy Laboratory}

1617 Cole Boulevard Golden, Colorado 80401 303-275-3000 • www.nrel.gov

NREL is a national laboratory of the U.S. Department of Energy, Office of Energy Efficiency and Renewable Energy, operated by the Alliance for Sustainable Energy, LLC.

NREL/FS-6A42-49156 • December 2010

Printed with a renewable-source ink on paper containing at least $50 \%$ wastepaper, including $10 \%$ post consumer waste.

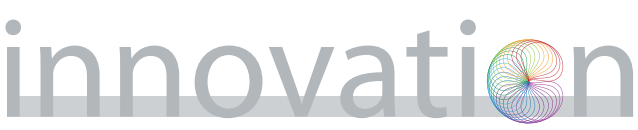

